\title{
LIVING IN THE TIMES OF HIV/AIDS: THE REPRESENTATION OF SPACE IN 120 BATTEMENTS PAR MINUTE
}

\author{
Rosidin Ali Syabana
}

Alumni Sastra Prancis Universitas Gadjah Mada, Yogyakarta, Indonesia e-mail: rosidinali421@gmail.com

\begin{abstract}
ABSTRAK
Penelitian ini bertujuan untuk memahami peran platform artistik dalam kontribusinya terhadap produksi ruang terkait sejarah LGBTQ dan HIV/AIDS di Prancis menggunakan film Prancis berjudul 120 Battements par Minute (2017). Film ini menceritakan tentang perjuangan organisasi transnasional, ACT UP Paris, untuk mendorong pembuat kebijakan dan perusahaan farmasi dalam mengembangkan pengobatan dan kebijakan publik yang lebih baik untuk pasien HIV/AIDS. Penelitian dilakukan dalam beberapa tahap, dengan menggunakan konsep representasi ruang Henry Lefebvre. Pertama, data dikumpulkan dalam bentuk gambar tangkapan layar dan narasi terkait tangkapan layar. Data tersebut kemudian diklasifikasikan dan dianalisis dengan menggunakan konsep ruang triadik Lefebvre dan interpretasinya dalam studi queer. Artikel ini menyimpulkan bahwa tubuh memainkan peranan penting sebagai mediator dalam praktik spasial. Praktik spasial yang direpresentasikan dalam film ini erat kaitannya dengan hierarki kekuasaan dan nilai dominan dalam masyarakat. Namun, tubuh queer berusaha mengubah ruang dominan menjadi queer dengan beberapa pendekatan baik di ruang privat maupun publik.
\end{abstract}

Kata kunci:

Sinema Prancis; HIVIAIDS; Henri Lefebvre; Queer; Studi spasial

\section{INTRODUCTION}

25 years after Act Up Paris (AUP) was established, a film titled 120 Battements par Minute (120 BPM) is broadcasted to commemorate AUP for their struggle during 1990s HIV/AIDS crisis. The film receives a great praise from the critics, which calls it "appeleurs de mémoire (memory recall)" for younger generations (Chémery et al., 2018). The story follows a group of activists Act Up Paris during the HIV/AIDS crisis in France in the 1990s narrated politically and economically. The film is political because it addresses the French government policy during the rampaging crisis. Meanwhile, it is economical because the pharmaceutical company is also involved in policy making. This dynamic makes the film rich in conveying the generational memory transfer as they are told based on the historical event by the member of AUP (Chémery et al., 2018; Desbarats, 2017). Furthermore, the film contributes to the discourse of transnational queer and HIV/AIDS history (Hann, 2020). However, it also questions the production of space, especially queer space. 


\section{SASDAYA,}

Gadjah Mada Journal of Humanities, Vol. 5. No. 2, 2021

The study of spatiality is developed significantly among social science and humanities scholars nowadays due to its complexities and interdisciplinary nature. Before social space as a concept appears, space is always perceived as concrete and mathematical. Henri Lefebvre (1991) disagrees with such thought and offers a concept of space as social, a space that is always in the production and reproduction process. He insists that people overlook spatial concepts in social activity because it is almost unrecognisable; social space is really close in our daily life activity and experience and it evokes social conflicts (Pasín, 2002; Udasmoro \& Noviani, 2021). For example, a pavement in Indonesia is a source of simple conflict between the pedestrian and street vendors because the latter block the walking access of the pedestrian who paid the tax for the infrastructure development. Meanwhile, street vendors use the space for their economic purpose. This dynamic highlight the space as social because it consists of elements and moments of social practice (Lefebvre, 1991: 8).

From a social perspective, Lefebvre offers a triadic form of space (Lefebvre, 1991: 33, 38-39). The first one is spatial practice that is an individual experience of the space where they live. Then, there is representational space, which refers to a space that is full of knowledge and power that determines the regulation and rule on the space lived (for example the knowledge from the architect and the political power from the policy maker) (Udasmoro \& Noviani, 2021). The last one is called representation of space which represents the vision and imaginary thought of the space found in literature, painting, film and other artistic platforms. The study of spatiality then transforms from using an objective approach to look at the space on the peripheral areas that concentrates on the fragmented experience from different subjects (Lukinbeal \& Zimmermann, 2006).

Even though Lefebvre lies his fundamental concept of social space from daily urban experience in France during the first industrial revolution, the development of spatial studies can be applied on the various media, for example film (Lukinbeal \& Zimmermann, 2006), especially when the concept offered by Lefebvre can be interpreted widely. Film profits the technology to capture daily activities in social space, in which the director is capable to experiment their ideas and also allow the audience to interpret the critique of the spatial practice (Swope, 2002). A film also aims to represent different individual spatial practices in response to their social relation and activity in the daily practice (Ducotey, 2020).

In the recent years, the study of spatiality intersects with queer studies (Ingram, 1993; Kinkaid, 2018; March, 2020; Oswin, 2008). Queer concept is closely entailed with the performativity in both public and private space (Butler, 1999). Thus, it also inhabits the social activity that produces lived experience of queer individual. Besides, queer studies and study of spatiality complement each other because both offer a possibility to engage with complex centre-border relations and its dynamic (Kinkaid, 2018; March, 2020). Queer studies also not only concerns about a mere sexual identification and expression, but, more than that, it also tackles the issue of sexual transmitted infection (Rees-Roberts, 2008).

The discourse about the relation between LGBTQ people and sexual transmitted disease has become prominent in recent years, notably in the work of film. We were here (2011), How to survive a plague (2012) and United in anger: a history of ACT UP (2012) are some examples of the motion picture that tackles the HIV/AIDS issue. Some literature also tries to engage similar problems. First, Harvey (2012) questions a transnational queer 


\section{SASDAYA,}

concept in educational video related to HIV/ADS in Sub-Saharan African film project Steps for the future. Combining political and queer studies, Harvey points out that homosexuality in Sub-Saharan Africa is deemed as an western imported ideology which does not in line with African cultural and religious value. He also finds that African society only understands that HIV/AIDS is a disease that can be propagated between heterosexual, which omits the existence of homosexual discourse in the nation. However, the project Steps for future tries to deconstruct such concept by providing individuals experience regarding being queer and suffering from HIV/AIDS.

Similar approach also has been done by Hart (2013) questioning the portrayal of romanticised HIV/AIDS in American media. He then tries to analyse two documentary films about the daily life of infected patients. The result of his research shows that the realistic portrayal of a life-death situation represented in the documentaries challenge the popular representation that usually overlooks the daily challenges the patient faces that opens a wider conversation regarding the intersection of queer and health studies. Furthermore, Hann (2020) takes a different approach by studying a theatrical performance called The Inheritance. She questions the loss of memory transfer of the HIV/AIDS crisis among young LGBTQ people. Using the concept of Utopia in Performance by Jill Dolan, she argues that The Inheritance provides a criticism of intergenerational memories of the crisis while providing a shared memory of suffering from the past, the present and the future.

Lastly, Cartwright (2016) problematizes the representation of HIV-positive bodies in the mainstream media. She uses the film Philadelphia (1993) as a research object and uses a concept of "digital restoration" to analyse the data. She argues that HIV/AIDS plays a significant role in the development of the city. The digital restoration here means that the film uses several fragmented clips from citizen who could capture the horror of the crisis that is overlooked by the generation nowadays, thus transforming a history between the industrialization and the pandemic, then proposing a new topography and history from the lens of queer experience. Other than that, the film also provides the shared memory of stigmatization and suffering experienced by LGBTQ people at the time to contribute on the development of queer history in Philadelphia.

This article, therefore, will provide a distinct approach to look at the connection between queer studies and study of spatiality using the film titled 120 Battements par Minute (120 BPM) by Robin Campillo. This article addresses the dichotomy of representation of space between private and public space. The private space, auditorium for instance, provides a representation of AUP's ambition and power to occupy a space. However, when they are outside in public, there are various kinds of contestation and confrontation between their values and the society's that create social conflict. That dynamic of space reflected on the problem raises two questions. First, how the film represents the subjective experience that contribute producing the history of space of queer and HIV/AIDS? Second, how does the film portray the process of queering the space? This article aims to deliver the example of analysis using a one component of Lefebvre's triadic space to understand the role of artistic platform in contributing, creating the dialogue and even reshaping the production of history and discourse of queer and HIV/AIDS in France. 


\section{METHOD}

The first step is the data collection. The data comes from the mise-en-scène that is captured partially and the description of the narration. The mise-en-scène collected consists of the spatial practice, both in the private and public, which AUP experiences throughout the film. From the data, they are classified on to two different groups, the one that tells the story about the relation between body and the spatial experience (spatial practice), and the one that tells the AUP's attempt to queering the space as a means of integration. The data will be analysed using the concept of representation of space (Lefebvre, 1991: 37-38). This article uses the particular concept because according to Lefebvre (1991), any artistic form belongs to the third category of triadic space that is the representation of space. This theory also provides a critical approach to understand the spatial practice and how it is related to the development of a history of space, in this article we are talking about the space for queer subject, which the film $120 \mathrm{BPM}$ attempts to narrate. With the help of interpretation of the Lefebvre's production of space in queer studies developed by some queer scholars (Ingram, 1993; Kinkaid, 2018; Oswin, 2008; Reed, 1996), the analysis on this article will heavily rely on the interpretation between body, space and the process of queering the space.

\section{RESULT AND DISCUSSION}

Queer spatiality can be defined as the concept of space that is experienced and represented by the non-traditional sexual orientation and gender identity that takes account on the Lefebvre's concept of space (Ingram, 1993; Kinkaid, 2018; Oswin, 2008). Regarding the debate of the body's experience in spatial practice, Reed (1996) takes on different definition of the "queer spatiality" due to the fluidity of the queer concept, Reed argues that it is hard to apply the queer concept to spatial study because

“No space is totally queer or completely un-queer-able, but some spaces are queerer than others. The term I propose for queer space is imminent: rooted in the Latin imminere, to loom over or threaten, it means ready to take place. For both advocates and opponents, the notion of queerness is threatening indeed. More fundamentally, queer space is space in the process of, literally, taking place, of claiming territory. (Reed, 1996: 64)"

The relation between the experience of queer body in the space and the imminent process of queering the space are critically represented on the $120 \mathrm{BPM}$. AUP member's body plays an important role to produce the queer space in response to the HIV/AIDS pandemic.

\section{RELATION BETWEEN BODY AND SPACE}

Lefebvre (1991: 33) argues that the space is constructed according to the hegemonic nature of dominant value, a dominant power that rules over the social and cultural practice in the society. In the case of $120 \mathrm{BPM}$, heteronormativity represents the dominant value that is hegemonic in the public space and limits the movement of LGBTQ people, which positions them as marginal when experiencing it (Kinkaid, 2018). However, the marginal access to the spatial practice is not completely shut down because the film 


\section{SASDAYA,}

Gadjah Mada Journal of Humanities, Vol. 5. No. 2, 2021

narrates the process of queering the space, or creating their own imminent domain (Reed, 1996).

Furthermore, Lefebvre (1991: 40) states that in spatial practice, the body plays an important role in the production of space because the body experiences and contributes in the dialogue and engagement with other subjects in the triadic space. One example shown in the film is when AUP conducts a so-called "violent" protest against Melton Pharm as their approach to express their disappointment to the slow response shown by the pharmaceutical company to fasten their research on antiretroviral drugs for the treatment of HIV/AIDS patients. As an active subject who voices the suffering of the patient, AUP tries to engage with the big company that is responsible for the development of public health care during the crisis.

The mise-en-scène follows a group of people, male and female, and one photographer from a national press who enter a building. In front of the receptionists, two members introduce themselves as ACT UP Paris who need to meet with the executive of Melton Pharm. As AUP does not have the meeting invitation, the receptionists decline their entry. However, AUP does not bother the instruction and forces them to enter the building. They begin to access the higher floor and chant "Melton Pharm, Assasin! (Melton Pharm, the assassin!)", and shoot a plastic containing a red liquid to the wall, expressing the blood of the HIV/AIDS patient that has been dead (Syabana, 2019). Melton Pharm employees are shocked as they have no idea of what is happening. It is a chaos as the executive also suddenly postpones the meeting and must deal with the AUP's interruption. Not long after the protest, the police arrive and escort AUP outside and as a defence mechanism, AUP members begin to shout to the police that their member is mostly a HIV-positive patient to make the police take the non-violence approach to neutralise the condition.

The scene described above represents the body that experiences space. The decision to go to the building, every step that they experience during their protest to Melton Pharm, the chant Melton Pharm, Assasin!, the emotion evoked when they confronted the executive, and the strategies to mess the building with the red liquid result from their daily experience as the HIV/AIDS patient. The body of each AUP's member has undergone various experiences, either from themselves or from the friend and the relative, regarding the pain suffered from HIV/AIDS. This shared individual experience crystallises to be a determination and frustration that is expressed on their disappointment towards Melton Pharm for the delay of the antiretroviral drugs development.

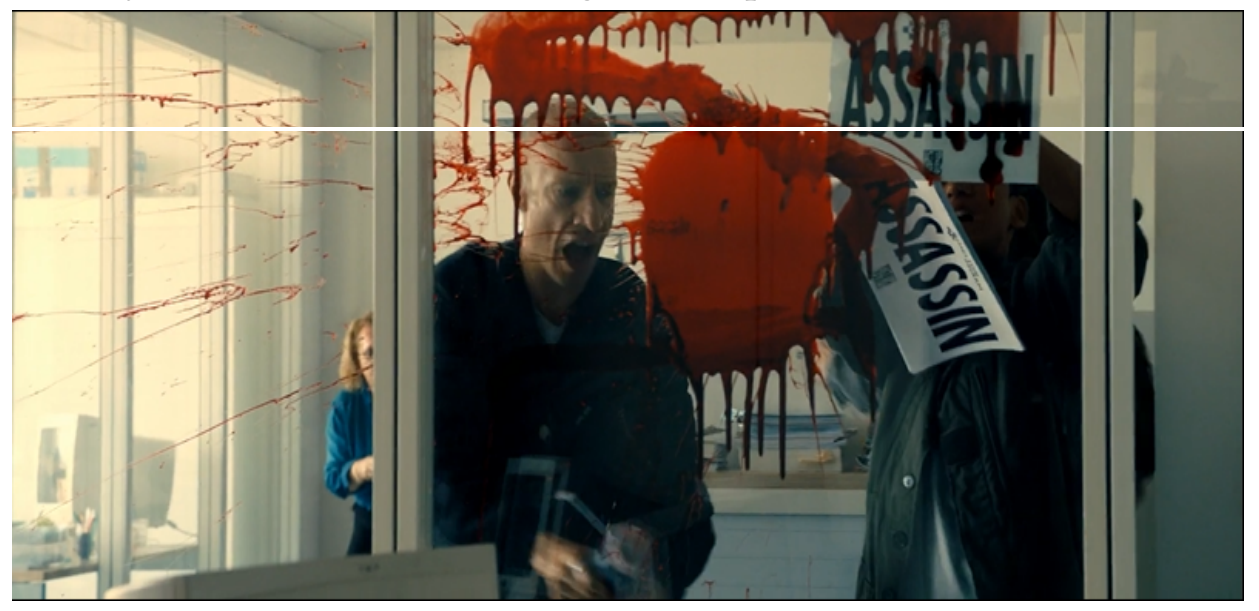




\section{SASDAYA,}

Gadjah Mada Journal of Humanities, Vol. 5. No. 2, 2021

On the other hand, Melton Pharm has different experience in dealing with the treatment of HIV/AIDS. As a pharmaceutical company, it is also difficult to develop a fast and effective treatment for the disease, especially in the 1980s where the outbreaks were still recently spreading. It takes time to understand the characteristics and the diffusion of the virus and Melton Pharm believes that they already take full responsibility to develop the drug. As the subject who has knowledge, power and access to develop the cure of HIV/AIDS, Melton Pharm belongs to the second triadic space's category, which is the representational space (Lefebvre, 1991: 38).

The pharmaceutical company possesses the capability to design the roadmap, alongside with the policy maker, of the development of the cure as they consist of scientists, experts, and businessmen. It is reflected in the film when they held the conference and the presentation of their research and development of the cure. AUP has also similar knowledge and they cannot be underestimated because the organisation consists of influential personnel as well, such as lawyer, student and activist. However, the difference lies in the political power that grants access to policy making. AUP does not possess such power because they are only an activist, who are only able to advocate and educate the danger of free sexual intercourse and HIV/AIDS.

Such contestation reflects the dynamic of the space Lefebvre implies in his book. Two different parties cross together in one space to tell their subjective experience regarding the problem each party encounters and produce a reciprocal relation to achieve the same goal. The ideology and idealism of each party collapse and construct the interaction that is reflected in the picture 1. However, the dominant subject can always rule over the others. In the case of $120 \mathrm{BPM}$, the pharmaceutical company has the higher power to determine the development of the HIV/AIDS treatment and public health policy at the time.

In comparison, $120 \mathrm{BPM}$ represents a different spatial practice in private space. The film uses the auditorium as the representation of a private and safe space for the AUP. In the auditorium, AUP member is allowed to express freely their opinion without being afraid to experience discrimination and punishment. In one particular mise-en-scène, the camera widely shoots the ambience inside the room where the leader of the ACT UP, Thibault, introduces the organisation to the new members. The auditorium is somehow empty as some ACT UP members conduct the protest to the AFLS (Alliance Française de Lutte contre le SIDA (French Alliance against the AIDS)). The discussion is rather packed as several people interrupt each other talking about the programs, the obituary of the fellow activist, and the introduction of the new members.

The tension rises when two members of AUP share different takes on the approach during the protest. The narration then moves back and forth between the discussion in the auditorium and the protest to the ALFS, which diverges from the initial plan. Sophie, who is against the act, believes that the action would bring negative consequences for the association and counter-productive from the AUP's objective. On the other hand, Sean, who initiated the act, insists that the action was justified, noting that it would bring the attention AUP seeks from the public, benefiting from the national exposure. Sophie only problematizes the violence and the humiliation directed to the presenter at the conference, for example the use of red liquid that a member throws at the presenter's face and the 


\section{SASDAYA,}

Gadjah Mada Journal of Humanities, Vol. 5. No. 2, 2021

handcuffing act by Sean and his friend while chanting "Bernard, démission! (Bernard, step down (from your position)!)".

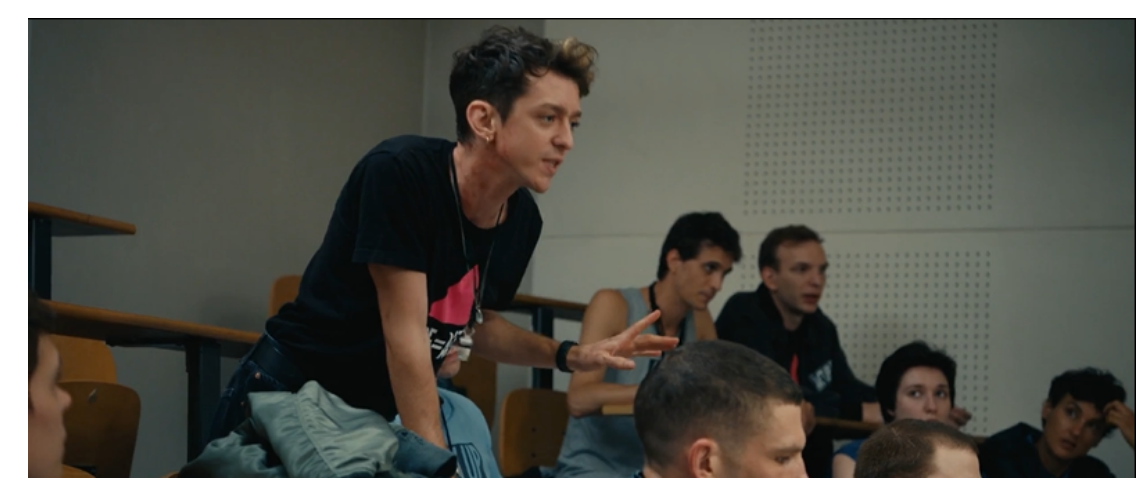

The picture 2 shows the different spatial practice experienced by each member of AUP manifested in the private space. Sophie's ideal spatial practice and Sean's contradict each other and produce the discourse about what is right and wrong in their protest activity. However, the private space provides a safe space for everyone to express their feelings without any hesitation of being discriminated against and judged. Sean can express his homosexual and feminine characteristic freely and Sophie can also express her boldness and fiery character. In 120 BPM, the body can be more liberated to produce and experience the space in the private area compared to the public one, especially with the homophobia and social rejection that overshadow their struggle to fight for better health public policy for the HIV/AIDS patient (Pratt, 1998). However, there is an attempt to express the sexual orientation and gender identity that confront the heteronormativity that will be explained in the next chapter although such spatial practice is limited.

Two examples above show the contrast difference of spatial practice experienced by LGBTQ people in France during the HIV/AIDS crisis. Their ideal production space contests the hegemonic value in the french society who still regards, during 1990s, the HIV/AIDS as an exclusive disease transmitted among gay people. Lefebvre (1991) confirms this idea that practice of power will always take part in the production of space because every subject has its own objective, ideology, and ideal spatial practice. In the 120 $\mathrm{BPM}$, the activists play their part to give vulnerable groups the voice to be heard by the public. Meanwhile, the pharmaceutical company provides the decision making and the knowledge to develop the cure for the HIV/AIDS patient.

The relation between the body and the production of space in the context of 120 $\mathrm{BPM}$, in conclusion, show the interesting dynamic and the knowledge about the history of queer in France. The film contributes to broaden the discourse of the importance the event of HIV/AIDS crisis on the queer studies' discussion. This also adds the process of intergenerational memory towards the LGBTQ youth in France of the traumatic and suffering experience of the health crisis that has been already overlooked and now regarded as the manageable disease (Cartwright, 2016; Shahani, 2016), while also reproduce and reconceptualise the space (Lefebvre, 1991) regarding the history of queer in french cinematic landscape. 


\section{SASDAYA,}

Gadjah Mada Journal of Humanities, Vol. 5. No. 2, 2021

\section{QUEERING THE SPACE}

A representational space refers to appropriated and imagined space that seeks to confront and challenge the representation of space (see Lefebvre, 1991: 38-39) because artists are allowed to experiment their ideas according to their imaginary and ideal spatial practice regarding the subject whom they tell in their stories. Regarding queering the space, Reed (1996) and Kinkaid (2018) also agree that queer space is also appropriation and imagination, in the sense that the word queering means a process of becoming in which the space contests the heteronormativity that dominates within the society.

As AUP is also a transnational political organisation, the film attempts to highlight its public activity through symbolism that shows their trial to claim the urban space as an act of actualisation. An example about queering space shown in the 120 BPM is through Pride Parade on the street. Historically, LGBTQ community started the Pride Parade on June 28, 1970 in New York to commemorate the 1969 Stonewall riots when there were a confrontation between a patrons of New York City gay bar and a routine police raid at the moment (Bruce, 2016). Since then, it creates novel landscape for LGBTQ community as a platform to come together to celebrate and to express their sexual identity.

Pride parades are often held on the street using colourful attributes, usually rainbow colours, and accompanied by people marching and dancing on the street and claiming the urban space, the street. to promote the visibility and validate the existence of LGBTQ people (Bruce, 2016). Film 120 BPM employs the Pride parade as a similar approach to reclaim public space for non-hetero people in France. One particular and interesting attribute that AUP uses in their Pride Parade is a truck. The film portrays trucks as a symbol of constant movement to validate their identity in the contestable space. It is interesting to note that throughout the film, most of the AUP member experiences several homophobic encounters on the public space (Syabana \& Udasmoro, 2019).

First, on the Metro after the protest at the AIDS conference, AUP members meet with elders who simply do not want to sit with them and show a disgusted expression towards male members due to their feminine characteristic and affection shown towards each other. Second, on their agenda to spread awareness of HIV/AIDS on the street, an AUP member encounters a young man who talk-trash and says that their action only spreads fears in society. Using the narrative provided by the film, AUP always tries to claim their position on the public space in spite of the threat and homophobic slur they receive on their action.

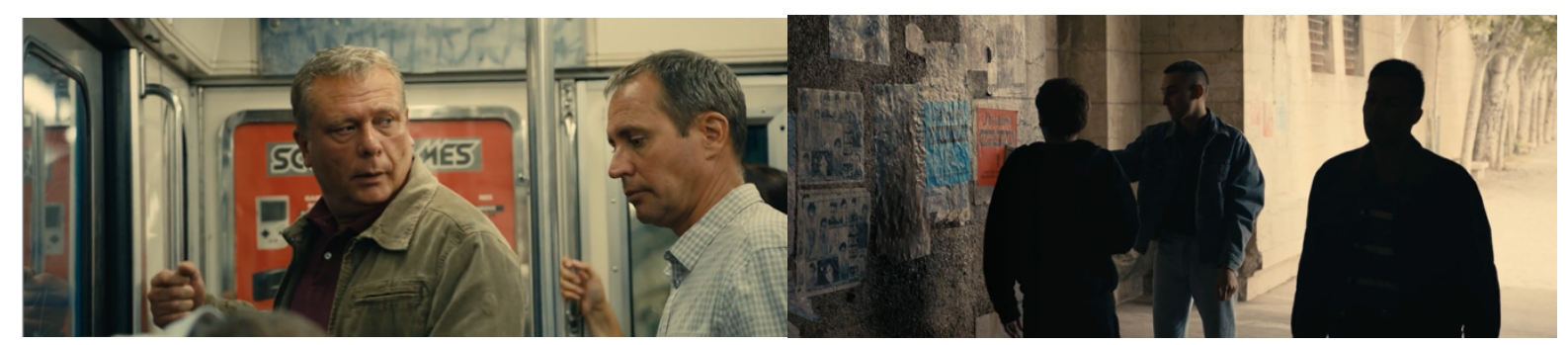

Among the struggles that AUP faces to push the government to take care of the HIV/AIDS crisis, the Pride Parade is, aside from usual street protest, the most outstanding feature that the film showed as the tools to contest the dominant space. The use of big transportation, such as trucks, implies their movement and their claim of the space at the 


\section{SASDAYA,}

Gadjah Mada Journal of Humanities, Vol. 5. No. 2, 2021

moment. Many films have used big transportation as a means to emphasise a constant movement to a certain goal (Strohmaier, 2021). In AUP, the transportation also serves as a symbol of mobility and individual expression of their sexual identity which aim to claim the space that was limited before due to the restrictions from the police or the social stigma.

Other than using transportations, the film also employs protest activity as a symbol of movements. Even most scenes of the film consist of protest and movement from members of AUP. As the film progresses, the type of movement is also various, ranging from peaceful protest to the more extreme protest that involves police (Syabana, 2019; Syabana \& Udasmoro, 2019). This shows that AUP tries to explore and negotiate their position in the spatial practice on the problem of sexuality and health. On one hand, AUP tries to claim the space for LGBTQ people in France by conducting Pride Parade. On the other hand, they also fight for better treatment access for people who suffer from HIV/AIDS. The two ideas presented on the film implies that the subject tries to contest the heteronormative space with the queer characteristic, meaning that they open the safe space for non-heteronormative people to validate their sexual identity.

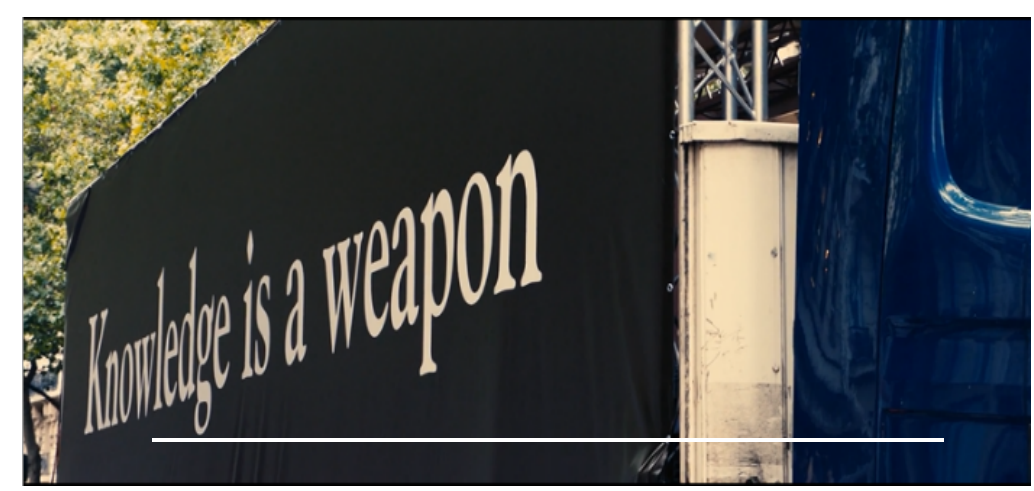

The mise-en-scène paralleled back-to-back from the backlash between the society and AUP to the existence of Pride Parade shows that the film tells the story from the point of view of LGBTQ community, which was constructed based on a lived experienced from the member of AUP at the time (Chémery et al., 2018). Hence, the scene of Pride Parade in the film shows AUP's attempt to integrate the queer space to the urban streets as a social transformation. This visual narrative creates a space to experiment and challenge the dominant norm to perform the self (Butler, 1999) and reimagine the history of space (Lefebvre, 1991: 48) regarding the queer history in France during the HIV/AIDS time. Other than that, queering the space signifies a process of becoming, a lived experience in spatial and political practice (Kinkaid, 2018) that the film exploits in the Pride Parade scene. Profiting many attributes connected to the non-heteronormative people, such as rainbow flag, confetti, and pink costumes, AUP celebrates their sexual identities in the public and also they reimagine the fluid sexuality by showing male cheerleaders as a statement to show the broad range of masculinity in french society. It shows that there is an essay to integrate themselves into French society. This integration, presented by their march on the street in the form of celebration, exhibits an attempt to claim the space and transform it on to a queer space (Oswin, 2008).

Furthermore, the film puts a court documentary to create suspense during the 1990s riots towards the french government. The riots represent a social movement to claim the queer space on the political contestation (Ernst, 1997). The riots demonstrate the attempt to tackle the health issue as AUP fights for better treatments for HIV/AIDS patients. This 


\section{SASDAYA,}

Gadjah Mada Journal of Humanities, Vol. 5. No. 2, 2021

issue offers interesting spatial practice experienced by AUP because of the dynamic between the individual experience (lived space) and the people who design the policy, research and development regarding the cure for HIV/AIDS crisis (perceived space). The dynamic between the two spaces recalls Lefebvre's notion of "spatial economy" which,

"valorises certain relationships between people in particular places (shops, cafes, cinemas, etc.), and thus gives rise to connotative discourses concerning these places; these in turn generate 'consensuses' or conventions according to which [...] such and such a place is supposed to be (Lefebvre, 1991: 56)."

This dynamic is the result of power relations among the subjects involved where the knowledge (savoir) and political leverage from the policy maker often dominates because they have the power to generate 'consensus' about the treatment and public policy during the HIV/AIDS crisis. Meanwhile, AUP as a society can only obey the 'consensus' as they live in the same space as the policy maker. Thus, the riots and the protest happen as a wake-up call for the government.

As the story progresses, few AUP's attempts were successful to shake the government's regulation for HIV/AIDS people. The film only shows how their action only gets them better publicity on the national television and news, but not on the development of the cure. Furthermore, the police also get involved in the demonstration to stop AUP from conducting more violence acts (Syabana, 2019). The film criticises the inability shown by the governments and pharmaceutical companies to provide better treatment for the HIV/AIDS patients when they employ the police forces to restrain the protest conducted by AUP. This interaction between lived space that is represented by AUP and conceived space represented by the policy maker and the pharmaceutical company clearly shows the spatial economy that circulates on the political contestation. However, the consensus or convention proposed by the government on the film clearly does not satisfy AUP that they must act and confront directly on the street, expressing their anger, anxiety and sadness towards their fellow member who has to suffer from the virus.

From the example and analyses provided above, the process of queering the space is a part of class struggle that the film narrative depicts how the LGBTQ people in France attempt to integrate their sexual value to the society in the form of parade and protest that possess different aim. However, as the dominant space still does not comprehend the need of these groups, the consensus among the society disagrees towards the value proposed. Thus, it creates a contestation among the subjects involved in the spatial practice to implement their discourse where usually the dominant space rejects the narrative of the outsider on the various models (Lefebvre, 1991: 57).

\section{CONCLUSION}

The film 120 Battements Par Minute offers a representation of space of two different categories. First, it conveys how the body, or the subject, experiences daily activity as a part of LGBTQ people in France. The film shows several struggles and challenge faced by them who live in the heteronormative society which portray the lived space told from the point of view of each members in the Act Up Paris. Furthermore, it also offers a lived experience of LGBTQ people as an activist who faces different and more complex subjects, such as the police, pharmaceutical company and the policy maker. 


\section{SASDAYA,}

Gadjah Mada Journal of Humanities, Vol. 5. No. 2, 2021

Second, the french film portrays the process of transforming the dominant space into queer space through several process, such as cultural and political activity. In each activity, the film offers a spatial practice that attempts to integrate the queer culture to the french society. The process of queering the space does not merely an easy attempt as, at the moment, french societal value does not accept the non-heteronormative sexual orientation. Hence, the space produces a contestation between two values that both parties try to dominate each other using knowledge (savoir) and power (both physical and ideological). The most interesting finding of the discussion is that the process of queering the space does not only involve a contestation of identity between "straight" and "not straight" cliché, but it also further develop the importance of health discourse in queer film.

Lastly, it is indeed not enough to only use a film to conclude the triadic space dynamic that Lefebvre offers in his book. Even though the film uses all three kinds of space that Lefebvre proposes (lived, perceived, and conceived), 120 Battements par Minutes falls only into the third category, which is a re-imagination of spatial practice told by the remaining members of Act Up Paris. It is then required to further research on the individual experience (spatial practice) and the policy making (representational space) in order to understand the HIV/AIDS and LGBTQ discourse in France during the crisis in 1990s. Nevertheless, the film provides significant contribution to the queer spatial studies because the visual narration of ACT UP in France is barely non-existent while the organisation had taken an important role in shaping the french LGBTQ identity in the present.

\section{REFERENCES}

Bruce, K. M. (2016). Pride Parades. In Pride Parades. New York: New York University Press.

Butler, J. (1999). Gender trouble: Feminism and the subversion of identity. New York: Routledge.

Cartwright, L. (2016). Learning From Philadelphia: Topographies of HIV/AIDS Media Assemblages. Journal of Homosexuality, 63(3), 369-386. https://doi.org/10.1080/00918369.2016.1124693

Chémery, V., Farjat, J., Gérard, S., Lalande, A., Vermeersch, L., \& Wahnich, S. (2018). Mémoire vive. Politique et sida dans « 120 Battements par minute». Vacarme, $N^{\circ}$ 82(1), 104-115. Retrieved from https://www.cairn.info/revue-vacarme-2018-1page-104.htm

Desbarats, C. (2017). [Review of Review of 120 battements par minute, by R. Campillo]. Esprit, (439), 141-145. Retrieved from https://www.jstor.org/stable/26503978

Ducotey, Y. (2020). Atlanta (FX, Donald Glover, 2016-), vers une transgression générique des frontières géographiques et sociales. TV/Series, (18). https://doi.org/10.4000/tvseries.4571

Ernst, C. E. (1997). Activisme à l'américaine? The Case of Act Up-Paris. French Politics and Society, 15(4), 22-31. Retrieved from https://www.jstor.org/stable/42844674 


\section{SASDAYA,}

Gadjah Mada Journal of Humanities, Vol. 5. No. 2, 2021

Hann, L. (2020). 'If we Can't Have a Conversation with our Past, then What will be Our Future?': HIV/AIDS, Queer Generationalism, and Utopian Performatives in Matthew Lopez's The Inheritance. English: Journal of the English Association, 69(265), 100-121. https://doi.org/10.1093/english/efaa014

Hart, K.-P. R. (2013). Constructing the "Unofficial" History of HIV/AIDS: SelfRepresentation in AIDS Documentaries. The Humanities Review, 11(1), 40-52. Retrieved from https://stjenglish.com/wp-content/uploads/HR2013_Kylo-PatrickHart.pdf

Harvey, D. O. (2012). Sub-Saharan African Sexualities, Transnational HIV/AIDS Educational Film and the Question of Queerness. In C. Pullen (Ed.), LGBT Transnational Identity and the Media (pp. 67-83). London: Palgrave Macmillan UK. https://doi.org/10.1057/9780230373310_5

Ingram, G. B. (1993). Queers in space. 1-22. Canada: University of Toronto. Retrieved from https://citeseerx.ist.psu.edu/viewdoc/download?doi=10.1.1.458.7318\&rep=rep1\&t ype $=$ pdf

Kinkaid, E. (2018). (en)Vision(ing) Otherwise: Queering Visuality and Space in Lefebvre's $\begin{array}{lll}\text { Production. GeoHumanities, } & 4(2), & 438-461 .\end{array}$ https://doi.org/10.1080/2373566X.2018.1447496

Lefebvre, H. (1991). The production of space (D. Nicholson-Smith, Trans.). Oxford: Blackwell.

Lukinbeal, C., \& Zimmermann, S. (2006). Film Geography: A New Subfield (Filmgeographie: ein neues Teilgebiet). Erdkunde, 60(4), 315-325. Retrieved from https://www.jstor.org/stable/25647919

March, L. (2020). Queer and trans* geographies of liminality: A literature review. Progress in Human Geography, 20(10), 1-17. https://doi.org/10.1177/0309132520913111

Oswin, N. (2008). Critical geographies and the uses of sexuality: Deconstructing queer space. Progress in Human Geography, 32(1), 89-103. https://doi.org/10.1177/0309132507085213

Pasín, A. E. C. (2002). La quotidienneté comme objet: Henri Lefebvre et Michel Maffesoli. Societes, no 78(4), 5-16. Retrieved from https://www.cairn.info/revue-societes-20024-page-5.htm

Pratt, M. (1998). The defence of the straight state: Heteronormativity, AIDS in France, and the space of the nation. French Cultural Studies, 9(27), 263-280. https://doi.org/10.1177/095715589800902701

Reed, C. (1996). Imminent Domain: Queer Space in the Built Environment. Art Journal, 55(4), 64-70. https://doi.org/10.2307/777657

Shahani, N. (2016). How to Survive the Whitewashing of AIDS: Global Pasts, Transnational Futures. QED: A Journal in GLBTQ Worldmaking, 3(1), 1-33. https://doi.org/10.14321/qed.3.1.0001

Strohmaier, A. (2021). Cinematic Spaces of 'the Arab Street': Mohamed Diab's Inverted Road Movie Clash (2016). In Media and Mapping Practices in the Middle East and North Africa (pp. 159-173). Amsterdam: Amsterdam University Press. Retrieved from https://www.degruyter.com/document/doi/10.1515/9789048541508-009/html 


\section{SASDAYA,}

Gadjah Mada Journal of Humanities, Vol. 5. No. 2, 2021

Swope, R. (2002). Science Fiction Cinema and the Crime of Social-Spatial Reality. Science Fiction Studies, 29(2), 221-246. Retrieved from https://www.jstor.org/stable/4241074

Syabana, R. A. (2019). Narasi Kambing Hitam Terhadap Kelompok LGBTQ pada Film 120 Battements par Minute (2017) Karya Robin Campillo (Skripsi, Universitas Gadjah Mada). Universitas Gadjah Mada, Yogyakarta. Retrieved from http://etd.repository.ugm.ac.id/penelitian/detail/174516

Syabana, R. A., \& Udasmoro, W. (2019). Un sujet marginal: Les communautés LGBTQ assimilées à de boucs émissaires dans le film 120 battements par minute. Francisola, 4(2), 106-114. https://doi.org/10.17509/francisola.v4i2.24201

Udasmoro, W., \& Noviani, R. (2021). Dinamika dan Politik Spasial: Sebuah Pengantar. In W. Udasmoro \& R. Noviani (Eds.), Politik Ruang: Spasialitas dalam Konsumerisme, Media, dan Governmentalitas (pp. iv-xxiv). Yogyakarta: Kanisius. 